Tyndale Bulletin 66.2 (2015) 197-216

\title{
WHAT ABOUT THE GIBEONITES? 1
}

\author{
William Ford \\ (wford@belfastbiblecollege.com)
}

\begin{abstract}
Summary
This article considers the story of the Gibeonites in Joshua 9-10 in the context of modern theological questions about the conquest of Canaan. It looks at the portrayal and perspectives of the four main groups in the story (kings, Gibeonites, Israel, and YHWH) and argues that reading Joshua 9 and 10 together shows that the Gibeonites were exempted from herem (destruction) because of their response to YHWH and Israel. Combined with the story of Rahab, this story suggests that the Canaanites as a whole are not doomed to destruction, but that their response to YHWH makes a difference.
\end{abstract}

\section{Introduction}

The divinely commanded slaughter of the Canaanites ${ }^{2}$ in the conquest narratives is arguably one of the most difficult problems for any theological or ethical use of the Old Testament in the modern world. Anyone who attempts to do so is likely to come up against some variant of the question: 'What about the Canaanites?'3

1 Earlier versions of this article have been read to the Tyndale Old Testament Study Group and the Trinity College Dublin Biblical Studies Research Seminar, and it has been improved by the comments and discussion. I am particularly grateful to my colleague Charlie Hadjiev for reading a draft and giving detailed feedback which has improved my argument in a number of places.

2 In this article 'Canaanites' is used in its more general OT sense as shorthand for the inhabitants of the land (e.g. Gen. 12:6) rather than the more specific sense of one of the seven nations (e.g. Deut. 7:1).

3 Wright and Anderson use the question as a title for their discussions in Christopher J. H. Wright, The God I Don't Understand: Reflections on Tough Questions of Faith (Grand Rapids, MI: Zondervan, 2008), 73-108; and Gary A. Anderson 'What about the Canaanites?', in Divine Evil? The Moral Character of the God of Abraham, ed. 
While the destruction of the Canaanites is a problem for many modern (and not so modern) readers, it is not obviously seen as a problem in the text itself. One could say that the problem for the text seems rather to be that the Canaanites are not destroyed, at least not totally.

Thus, there are various brief mentions in Joshua 13-21 of groups of Canaanites who survive 'to this day'. ${ }^{4}$ However in Joshua 1-12 two exceptions are given considerable prominence: Rahab and her family in chapters 2 and $6^{5}$ and the Hivites of Gibeon (henceforth the Gibeonites) in chapters 9 and 10. This article will focus on the Gibeonites. ${ }^{7}$ This is partly because more has been written on Rahab than the Gibeonites, but mainly because they are the more difficult case for two reasons. First they are a larger group than Rahab, as they comprise four towns rather than one family. Thus their exemption from destruction is more striking. Secondly their method of gaining acceptance is more dubious. Although both use deception, Rahab lies for Israel, whereas the Gibeonites lie to Israel.

The Gibeonite story comes immediately after the stories of Achan and $\mathrm{Ai}$ in chapters 7-8. It begins the block of material in chapters 9-11 and serves as the initial reason for the campaigns summarised therein.

Michael Bergman, Michael J. Murray, and Michael C. Rea (Oxford: OUP, 2011), 269-91. (See chs. 2, 3, 5, 8, and 10 for further focus on the issue of the conquest).

Other recent works that focus on this issue in whole or part include Paul Copan and Matthew Flannagan, Did God Really Command Genocide? Coming to Terms with the Justice of God (Grand Rapids, MI: Baker, 2014); Eryl W. Davies, The Immoral Bible: Approaches to Biblical Ethics (London: T \& T Clark, 2010); Douglas S. Earl, Reading Joshua as Christian Scripture, JTISup 2 (Winona Lake, IN: Eisenbrauns, 2010); Peter Enns, The Bible Tells Me So: Why Defending Scripture Has Made Us Unable to Read It (New York: HarperCollins, 2014), 29-70; Eric Seibert, The Violence of Scripture: Overcoming the Old Testament's Troubling Legacy (Minneapolis, MN: Fortress Press, 2012), 95-114; Heath A. Thomas, Jeremy Evans and Paul Copan, eds., Holy War in the Bible: Christian Morality and an Old Testament Problem (Downers Grove IL: IVP, 2013); Stephen N. Williams, 'Could God have Commanded the Slaughter of the Canaanites?', TynBul 63.2 (2012), 161-78.

4 13:13; 15:63; 16:10; cf. 17:12-13. See Gordon Mitchell, Together in the Land: A Reading of the Book of Joshua, JSOTSup 134 (Sheffield: JSOT, 1993): 152-84.

5 There is also the comparable, but shorter, story in Judg. 1:22-26.

7 The focus of this article is primarily theological. For wider details on the Gibeonites the most detailed work is Joseph Blenkinsopp, Gibeon and Israel: The Role of Gibeon and the Gibeonites in the Political and Religious History of Early Israel (Cambridge: CUP, 1972). A useful modern discussion of various issues is John Day 'Gibeon and the Gibeonites in the Old Testament', in Reflection and Refraction: Studies in Biblical Historiography in Honour of A. Graeme Auld, ed. Robert Rezetko, Timothy H. Lim, and W. Brian Aucker (Leiden: Brill, 2007), 113-37. 
Chapter 9 details the deception that the Gibeonites practise upon Israel. Instead of attacking, they pretend that they are from a far off land, and seek a covenant with Israel. Israel is deceived and makes the covenant. Shortly thereafter Israel realises that the Gibeonites live close by and that they have been tricked. They fear to break the covenant nonetheless and spare them, but make them servants for the shrine.

In chapter 10 an alliance of southern Canaanite kings attacks Gibeon, who appeals to Israel for help. With the help of YHWH Israel beats the armies, kills the kings and carries out a campaign or raid against the southern Canaanites, putting the kings and remaining inhabitants to herem. ${ }^{8}$ In contrast the Gibeonites, themselves Canaanites, are not put to herem, but rather survive in association with Israel.

If one question raised by Joshua $1-12$ is 'What about the Canaanites?' in the sense of 'Why were the Canaanites wiped out?', then one question raised by Joshua 9-10 is 'What about the Gibeonites?' in the sense of 'Why weren't the Gibeonites wiped out?' 9 This article will draw out some theological issues from the Gibeonite question, and see how they interact with the larger Canaanite one.

There have been a number of larger works on or including Joshua which have considered the theological issue of the Gibeonites. In the first volume of his literary study of the Deuteronomistic History, Moses and the Deuteronomist, Polzin argues that the dominant voice of Joshua is what he describes as 'critical traditionalism' rather than 'authoritative dogmatism' (the two voices that he perceives in the Deuteronomistic History). ${ }^{10}$ He sees the stories of Rahab and the Gibeonites as a meditation upon the status of Israel in relationship to YHWH as set out in Deuteronomy.

In the second chapter of his Into the Hands of the Living God, Eslinger looks at the ironic statements about Rahab and the Gibeonites. In contrast to Polzin he argues that the narrator is using these stories to

8 The fullest treatment of herem is found in Philip D. Stern, The Biblical Herem: A Window on Israel's Religious Experience, Brown Judaic Studies 211 (Atlanta, GA: Scholars Press, 1991). I am assuming the most problematic understanding of herem when applied to people, that of destruction.

9 Deut. 7:1 explicitly lists the Hivites (of whom the Gibeonites form a part - Josh. $9: 7 ; 11: 19)$ as one of the seven nations to be put to herem.

10 Robert Polzin, Moses and the Deuteronomist: A Literary Study of the Deuteronomic History Part One: Deuteronomy, Joshua, Judges (New York: Seabury, 1980), chapter 3, esp. 117-23. 
attribute to both Joshua and YHWH the failure fully to conquer the Canaanites. ${ }^{11}$

In Every Promise Fulfilled and his later Joshua commentary, Hawk also analysed the juxtaposition of seemingly contrary reports in Joshua, including the contrast of Rahab, Achan, and the Gibeonites. He argues that these contrasts are a deliberate part of the plot or plots, in order to challenge the reader's perception of reality and identity, and resonate with the difficulty of applying dogma to life experience. ${ }^{12}$

Most recently in his Reading Joshua as Christian Scripture, Earl has picked up Hawk's focus on identity and provided a theological interpretation of Joshua as Christian scripture, seeing it as a foundational myth for Israel, with its primary use being the formation of Israelite identity. Rahab, the Gibeonites, and Achan are liminal figures who challenge an easy or dogmatically exclusive understanding of identity. He argues for a symbolic reading of Joshua, as the way that it would have been read as part of the Old Testament, and a way in which it can be read by Christians today. ${ }^{13}$

One thing that all of these approaches have in common is the point that the narrative of Joshua is far more complex than an initial reading might suggest. This complexity is clearly present in the story of the Gibeonites, which is not an easy passage to interpret theologically, lacking clear divine or narratorial judgement of the events. ${ }^{14}$ Instead we have the comments and responses of the four main groups or persons in Joshua 9-10: the Canaanite kings, the Gibeonites, Israel and YHWH himself.

This article will examine these four groups, looking at the way that they are portrayed in these chapters, and considering the Gibeonite question from their perspective insofar as it can be deduced from the text. These portrayals will then be combined to consider the overall perspective of the text or narrator. This perspective will be compared

11 Lyle Eslinger, Into the Hands of the Living God, JSOTSup 84, Bible and Literature Series 24 (Sheffield: Almond, 1989), 25-54, especially 44-52.

12 L. Daniel Hawk, Every Promise Fulfilled: Contesting Plots in Joshua (Louisville, KY: Westminster/John Knox, 1991), especially ch. 4; L. Daniel Hawk Joshua, Berit Olam (Collegeville, MN: Liturgical, 2000), 135-54.

13 See, e.g. Earl, Reading, 49, 63, ch. 9.

14 Earl, Reading, 160. Similar ambiguities have been noted and discussed in the earlier encounter between the sons of Israel and the Hivites (of Shechem) in Gen. 34. See chs. 4 and 5 of Robin Parry, Old Testament Story and Christian Ethics: The Rape of Dinah as a Case Study, Paternoster Biblical Monographs (Milton Keynes: Paternoster, 2004). 
with the immediate context in Joshua and with comparable stories in the wider Old Testament to see what illumination is shed on the question and what theological issues emerge. This approach could be summarised as inductive, combining a close reading of the narrative with a wider canonical focus.

\section{Portrayal of the Four Groups}

\subsection{The Kings}

At the beginning of both chapters 9 and 10 , we see the response of the Canaanite kings to what they hear of YHWH and Israel. In 5:1 they were paralysed with fear, but in 9:1-2, 10:1-5 (and 11:1-5) they respond with military opposition. From their perspective Israel would be the enemy, a dangerous invader who must be resisted with force. In 10:1-5 the king of Jerusalem notes that the not insignificant Gibeonites have made peace with the enemy, thus effectively threatening his independence. The resulting joint assault of the southern Canaanite kings show that they now view the Gibeonites in a similar way to Israel (9:1-2).

This perspective would be similar to that of a number of recent postcolonial readings of Joshua, following Warrior's now classic article where he spoke of reading the conquest story through Canaanite eyes. ${ }^{15}$ Such postcolonial readings would share an opposition to the conquest ideology of the book, and would probably see the Gibeonites as traitors to the rest of the Canaanites. ${ }^{16}$ The kings, however, are not the main group of Canaanites in Joshua 9-10. Arguably their main

15 Robert Allen Warrior, 'Canaanites, Cowboys and Indians: Deliverance, Conquest and Liberation Theology today', Christianity and Crisis (1989), 261-65, esp. 262. Warrior's comment was a partial inspiration for this article's focus on different perspectives, although it is unlikely that he would agree with its conclusions.

16 In an article building on Warrior, Bailey critiques the ideology of the text, seeing the portrayal of Rahab, the Gibeonites, and the kings as depictions of an enemy by the invader, serving as warnings to the indigenous peoples. (Randall C Bailey, 'He Didn't Even Tell Us the Worst of It!', Union Seminary Quarterly Review 59 (2005), 15-24.) This raises the question of how one reads through Canaanite eyes when the depiction of the Canaanites is in Israel's scriptures. Postcolonial criticism of the conquest is a growing modern perspective that needs engagement. However as a white, male, British writer I am aware enough of my own privilege to avoid trying to engage with this issue without sufficient care and space, which is not possible within the constraints of this article. 
function in the story is as a contrast with the smaller Canaanite group, the Gibeonites. ${ }^{17}$

\subsection{The Gibeonites}

Immediately after the kings' response in 9:1-2 we hear of the Gibeonites' response in 9:3-4a. By this juxtaposition, the narrator is drawing a strong contrast between the two groups of Canaanites. They both hear of what Israel and their God have done, but they respond very differently: cunning in contrast to opposition. ${ }^{18}$

While Israel views this cunning deception negatively for obvious reasons (vv. 16-23), there is no clear narratorial or divine censure in the passage. The Hebrew word used, ormah, can be positive as well as negative in meaning. In the culture of the time such an act could even be seen as positive in nature. ${ }^{19}$

The focus of their deception is their location. They speak of coming from 'a (very) distant land' $(9: 6,9)$ and they fake evidence of a long journey. The reason for this focus can be found in the laws of war in Deuteronomy 20, which distinguish between those outside the land with whom a covenant of vassalage can be made (vv. 10-15) and those inside the land who are to be put to herem (vv. 16-18, cf. 7:1-5). ${ }^{20}$ The Gibeonites are portrayed as being aware of these laws and they aim to

\footnotetext{
17 See Earl, Reading, 161.

18 Lawson G. Stone, 'Ethical and Apologetic Tendencies in the Redaction of the Book of Joshua', Catholic Biblical Quarterly 53 (1991), 25-35. Stone, 28-35, identifies six texts that show a 'report-response' motif: 5:1; 9:1-2; 10:1-5; and 11:1-5 (kings); 2:9-11 (Rahab); and 9:3-4a (Gibeonites). Different Canaanites hear of what YHWH and Israel have done but respond in different ways.

19 Ormah has the basic meaning of 'prudent' or 'crafty' and can be positive (mainly in Proverbs) or negative (mainly elsewhere). More generally, there are other trickery motifs in earlier stories which are not condemned, e.g. Jacob. See Mitchell, Together, 168; Earl, Reading, 159; Hartmut N. Rösel, Joshua, Historical Commentary on the Old Testament (Leuven: Peeters, 2011), 147.

20 Lohfink argues that Deut. 20:10-11 also applies to the cities in the land, and therefore that Israel was obliged to offer surrender to them as well as cities outside the land. Only on a refusal was the herem in 20:16-18 to be applied. (N. Lohfink, 'חרם', TDOT 5:180-99, esp. 197.) However if the Gibeonites had been offered surrender terms similar to those which they seek (compare v. 11 with Josh. 9:8, 21), this would remove the need for the deception focused on location which is central to the story. In contrast Rofé argues that v. 15 delimits the application of the whole of vv. 10-14, so that an offer would not be made within the land. (A. Rofé, 'The Laws of Warfare in the Book of Deuteronomy: Their Origins, Intent and Positivity', JSOT 32 [1985], 23-44, esp. 28-29.) This would fit better with the Gibeonite story.
} 
portray themselves as those outside the land so that they may seek a covenant with Israel. ${ }^{21}$

When challenged about why they have come, the Gibeonites explain their desire for a covenant in verses 9-10 as a response to "the name of YHWH your God', having heard of the acts of YHWH and Israel in Egypt and against Sihon and Og. ${ }^{22}$ When the deception is discovered and Joshua asks them to explain it, they give a further explanation in verse 24; that they had heard that YHWH had given the land to Israel and as a result they feared for their lives, leading to the deception.

Comparing the two explanations, it is clear that the first explanation in verses 9-10 has been phrased to take account of the deception. There is no mention made of Jericho and $\mathrm{Ai}$, whereas in verse 3 the narrator explains that these were the events that caused them to seek the treaty. This omission is presumably because those from a far land would not yet have heard of the conquest of Jericho and Ai. However this does not necessarily mean that the points made about YHWH in verses 9-10 are deceptive. The explanation in verse 24 does not contradict the explanation in verses 9-10. Instead it adds to it, recontextualising it back into the perspective of those dwelling in the land.

In both cases the underlying reason is an acknowledgement of YHWH and what he has done for Israel. Taking verses 9-10 and verse 24 together creates a message not dissimilar to that of Rahab in 2:9-11. YHWH has defeated Egypt, Sihon, and Og (2:10, 9:9-10), he has given the land to Israel $(2: 9 ; 9: 24)$, he has caused the inhabitants to fear Israel $(2: 9,11 ; 9: 24)$, and destruction has been and/or will be involved $(2: 10$, 9:24). ${ }^{23}$ The focus on YHWH $(2: 11,9: 9)$ is the reason for the speaker siding with Israel, and thus with YHWH.

It is true that the Gibeonites' words are less exalted than those of Rahab. ${ }^{24}$ However Rahab's confession of YHWH is so impressive that Jewish and Christian tradition has seen her as a key example of the

21 For more details on the ruse see Robert P. Gordon, 'Gibeonite Ruse and Israelite curse in Joshua 9', in Covenant as Context: Essays in Honour of E. W. Nicholson, ed. A. D. H. Mayes and R. B. Salters (Oxford: OUP, 2003), 170-86, esp. 170-78.

22 Mention of Yhwh's name here probably refers to his fame from these acts $(1 \mathrm{Kgs}$ 8:43), although it could also refer to his character (Exod. 34:5-7). On occasion it could almost represent God himself (Deut. 12:5). See Allen P. Ross, 'שِّه', NIDOTTE 4:146-51.

23 The Gibeonites use sh-m-d (9:24) whereas Rahab uses h-r-m (2:10). However a similar idea of destruction is intended.

24 See Gordon, 'Ruse', 175, 177. 
righteous proselyte or ideal convert. ${ }^{25}$ It is noticeable that in the conquest narrative the two confessions of YHWH's acts on behalf of Israel are made, not by Israel, but by two groups of Canaanites.

It is also true that in verse 24 the Gibeonites seem to be motivated by a desire to save their own skins rather than anything nobler. However this does not preclude their response from being a genuine acknowledgement of YHWH. Looking at it from their perspective, as a people under threat of herem from this God, it would be inappropriate to expect much more of them. Similarly, looking at the wider deception from their perspective, one could ask what else they could have done in their position. ${ }^{26}$ Apart from fighting Israel like the kings, or waiting to be destroyed like Jericho and $\mathrm{Ai}$, any direct approach to Israel admitting their location and seeking a covenant would seem doomed to failure. $^{27}$

Their final status is ambiguous. ${ }^{28}$ They are cursed by Israel to servitude as hewers of wood and drawers of water, thus becoming the servants they claimed to be in verse $8 .{ }^{29}$ However the hewing and drawing is for YHWH's sanctuary, which suggests an association with that which is at the centre of Israel. ${ }^{30}$ Moreover it resonates with Deuteronomy 29:10 [29:11 English] which speaks of the aliens in the midst of the camp who hew the wood and carry the water. The use of the same four words in both places for hewing wood and drawing water (Deut. 29:10; Josh. 9:21, 23, 27) strongly suggests that there is a link between these passages. ${ }^{31}$ These aliens stand with Israel to enter into the covenant with YHWH, and the wider passage has a forward-looking stance, speaking of 'those who are not here today' (v. 14). Reading

25 For more details see Judith Baskin, 'The Rabbinic Transformations of Rahab the Harlot', Notre Dame English Journal 11.2 (1979), 141-57.

26 See Rösel, Joshua, 155.

27 While Rahab does not deceive Israel, the situations are different. Rahab could not deceive the spies because they knew she was Canaanite. Moreover she had less need to deceive them, as at the time she was in a position of power over them, being their safety in a hostile city. In contrast the Gibeonites had no power over Israel and thus no leverage to push for a binding agreement.

28 See Hawk, Joshua, 148-49.

29 For a more detailed discussion of the curse see Gordon, 'Ruse', 178-86.

30 Like Rahab, they remain 'in the midst of Israel' to this day (Josh. 6:25; 9:27).

31 See Polzin, Moses, 117-21. 
canonically, as the initial Gibeonite deception echoes Deuteronomy 20, so the final status of the Gibeonites echoes Deuteronomy 29.32

The Gibeonites side with Israel and their God against their own people, and the reaction of the kings in 10:1-5 emphasises this. In turn the Gibeonites respond, not by seeking to pacify or side with the kings, but by calling out to Israel for help (10:6). Thus, notwithstanding their methods, their response to Israel and YHWH is positive. This is explicitly contrasted to the negative response of the Canaanite kings. ${ }^{33}$

\subsection{The Israelites}

The theme of response continues when we consider Israel. In Joshua 910 Israel has to decide how to respond to the Gibeonites on three separate occasions. The first decision (9:6-15) is whether to make a covenant with them or not. Israel also knows the laws of war, as the Israelites question the Gibeonites about their location. However in verse 14 the narrator notes that they did not seek YHWH's guidance in this matter. This explicit narratorial comment suggests that they should have done this. Unlike the Gibeonites Israel could and should have acted differently.

Then (9:16-27) the Israelites have to decide how to respond to the deception when it is discovered. They have a difficult decision to make. On the one hand they are under divine instruction to herem the Canaanites, which they now realise includes the Gibeonites. On the other hand they have made a covenant with the Gibeonites, including an oath sworn in the name of YHWH, which would be a very serious matter in the ancient Near East. ${ }^{34}$ They must decide whether to keep the oath and break herem, or to keep herem and break the oath. Once again they do not seem to enquire of YHWH, although this is not explicit as in verse 14. Their decision is that they cannot break the oath sworn in YHWH's name or 'wrath will come upon them' (presumably from

\footnotetext{
32 One argument against this is to note that the portrayal of the aliens in Deut. 29 is positive, whereas in Josh. 9 it is laid upon the Gibeonites as a curse. However, to anticipate the next section, the portrayal of Israel is not wholly positive in Josh. 9. Therefore a curse from Israel need not necessarily imply a curse from God, but could be the mean of the Gibeonites becoming the aliens described in Deut. 29.

33 See Stone, 'Ethical', 34.

34 Pekka M. A. Pitkänen, Joshua, Apollos OT Commentary 6 (Nottingham: Apollos, 2010), 212; F. Charles Fensham, 'The Treaty between Israel and the Gibeonites', Biblical Archaeologist XXVII.3 (1964), 96-100, esp. 98. The fact that the oath was gained by deception would not have given Israel a reason to nullify it.
} 
YHWH). Thus their compromise is the Gibeonites' servitude. The text gives no explicit evaluation of this decision. ${ }^{35}$

Finally (10:1-14) they have to decide how to respond to a call for help from the Gibeonites. In contrast to the previous two occasions there are no details about how the decision is made. They simply come to the Gibeonites' aid, thus upholding the covenant.

Comparing the portrayal of the Israelites and the Gibeonites we see that both are motivated by fear of divine action $(9: 14,24)$. However the Gibeonites emphasise YHWH, whereas the Israelites tend to ignore him. ${ }^{36}$ The Gibeonites' response is positive even if their methods are questionable. Judging the Israelites' responses is more difficult. Arguably the Gibeonites are portrayed more positively than the Israelites in these encounters. ${ }^{37}$

\subsection{YHWH}

In Joshua 9 YHWH is only referred to in a passive way: the Gibeonites twice name him as a reason for their actions (vv. 9-10, 24); Israel fails to enquire of him (v. 14) but swears an oath in his name (vv. 18-19), and the Gibeonites become hewers and drawers for his altar (vv. 23, 27). There is no comment or action from YHWH of any kind, and therefore there is no response to or evaluation of any human actions. This makes YHWH's perspective quite difficult to ascertain.

However in Joshua 10 things are rather different. YHWH strongly supports Israel's fight in defence of the Gibeonites. He encourages Israel (v. 8), panics the Canaanites into routing (v. 10), rains hailstones down upon the fleeing Canaanites to such an extent that he kills more than the pursuing Israelites do (vv. 10-11), and finally he listens to Joshua and halts the sun (vv. 12-14). ${ }^{38}$ Arguably it is YHWH that wins

\footnotetext{
35 This has not stopped commentators from discussing it. For two alternative positions see John Calvin, Commentary on Joshua (Classic Christian Ethereal Library), 122-25, accessed 23 October 2015, http://www.ccel.org/ccel/calvin/calcom07.pdf; C. F. Keil and F. Delitzsch, Joshua, Judges, Ruth (Edinburgh: T \& T Clark, 1872), 100-1.

36 See Hawk, Joshua, 143-46 for a more detailed comparison, including the united nature of the Gibeonites compared to the fragmented nature of Israel.

37 This is less the case in 10:1-14 where both groups are portrayed very briefly, and the focus is on YHWH.

38 Day, 'Gibeon', 120-22, summarises a number of different interpretations of this passage: the sun literally stopping; a meteorite; a total eclipse; the sun and moon as gods; an omen; and a storm with hailstones. In this context it is enough to note that, whatever the exact details, it is understood as impacting on the battle positively for the Israelites.
} 
the battle, with Israel simply supporting him. The narratorial statement in verse 14 emphasises the unique divine intervention.

This raises the question of why YHWH is so surprisingly active in fighting in defence of Gibeon and Israel. ${ }^{39}$ After all, the Gibeonites have just tricked his people, and his people have not consulted him in making a covenant that goes against his herem command. At the very least we might expect him to withhold his support in battle, and allow Gibeon to be wiped out by the other Canaanites. This might also cause Israel to suffer losses which could be seen as a lesson not to do such things again. Instead we have such positive divine involvement that it is hard to think of another battle in the Old Testament where YHWH is more explicitly and actively involved. Therefore it seems from his actions that YHWH does not think that the Gibeonites should be wiped out.

\subsection{Combining the Portrayals/Narrator}

The different portrayals and perspectives discussed above can be brought together to deduce the narrator's perspective on the Gibeonite question. The Gibeonites' deception in order to seek a covenant receives no explicit narratorial censure. Instead, their response is sharply contrasted with the Canaanite kings by the juxtaposition of 9:12 and 9:3-27 as a positive rather than negative response to what they have heard of YHWH. The only possible censure in the passage is Israel's failure to enquire of YHWH (v. 14), which is in contrast to the Gibeonites' ongoing focus upon YHWH. ${ }^{40}$ Thus the Gibeonites are portrayed more positively than either the kings or the Israelites, making them the most positively portrayed of the three human groups in the story ${ }^{41}$ There is no censure of either of Israel's later decisions: to spare the Gibeonites in accordance with their oath, and to march to defend Gibeon when requested to help. In contrast, YHWH (who has been

\footnotetext{
39 See Hawk, Every, 90-91.

40 One could argue based on 9:14 that the narrator is suggesting that had Israel enquired of YHWH he would have responded by revealing the deception. As a result the covenant would not have been made and the Gibeonites would have been subject to herem. However v. 14 focuses on the portrayal of Israel and their actual inappropriate actions, rather than the portrayal of YHWH and his hypothetical actions. Focusing on the latter would inappropriately change the nature of the story where Israel's error and YHWH's lack of action (in Josh. 9) are important elements of the overall perspective of the text.

41 Similarly in Josh. 2 Rahab is far more positively portrayed than both Israel (represented by the spies) and the Canaanite king (of Jericho).
} 
silent up to this point) intervenes decisively in favour of Israel and Gibeon.

Taking all of these points together, the narrator's perspective agrees with that of YHWH (as we might expect) that the Gibeonites should not be wiped out. However according to Deuteronomy 7 and 20 the Gibeonites as inhabitants in the land should be subject to herem. Therefore sparing them would appear to be a breach of the herem commands, which make no exceptions. To test this seeming breach we will consider other clear examples of herem breach in Joshua and the wider Old Testament.

\section{Herem Breaches in Joshua and the Wider Old Testament}

The first point of contrast is the battles at Ai. The initial battle in Joshua 7 is a shocking defeat, which is correctly understood by Israel as divine displeasure due to sin. YHWH is willing to let his people fall in battle when they sin; a pattern that is repeated elsewhere in the OT.42 The narrator makes it clear that Achan's sin is not simply theft, but the breaching of herem $(7: 1,11-12)$. This has potentially lethal consequences for Israel, as it causes Israel to become herem (v. 12), and thus subject to destruction similar to Jericho and Ai. It is so serious that the herem has to be purged from Israel by the destruction of Achan and everything associated with him (vv. 15, 24-26). Only then does Israel gain victory at $\mathrm{Ai}$ in chapter 8 .

Immediately after this Israel makes a covenant with the Gibeonites. In doing this it would seem that Israel has breached herem just as Achan did beforehand. Therefore one might expect a repeat of the first Ai defeat in the battle of Gibeon, rather than the victory which does take place. The same expectation would apply in the case of Rahab and Jericho. As with the Gibeonites, an oath is made to spare a family within the land who should be subject to herem. Yet at Jericho YHWH fights for Israel explicitly, bringing the wall down, and there is no word of condemnation from YHWH for any herem breach, even when Joshua

42 Num. 14:44-45; Deut. 28:25; Judg. 2:14-15; 1 Sam. 4:10-11 etc. 
explicitly excludes Rahab from herem $(6: 17 b, 22) .{ }^{43}$ If Rahab lives among the Israelites 'to this day' in 6:25 then she could not be herem in their midst as Achan was. ${ }^{44}$ Similarly, the Gibeonites are made servants of the altar, which would be very dangerous if they were bringing herem into the midst of Israel. The whole sacrificial system could be polluted.

We can continue this contrast by looking briefly at two other examples of herem breach in the wider Old Testament. In 1 Samuel 15 King Saul is condemned for sparing King Agag and the 'best' of the Amalekites, when YHWH has commanded him to herem them (v. 3). There is explicit condemnation from Samuel including that Saul has been rejected as king (vv. 17-23), and two narratorial comments that YHWH 'repented' or grieved that he had made Saul king (vv. 11, 35). Saul's breach of YHWH's herem command is seen as rejection of YHWH, which leads YHWH to reject Saul. Short of death, the divine response could hardly be more negative.

In 1 Kings 20:35-43 there is an enigmatic little passage. YHWH has helped Ahab, king of Israel to defeat Ben-Hadad, king of Aram in two battles that have features of what is now being called 'YHWH war', and thus resonate with both 1 Samuel 15 and Joshua (including the falling of the wall at Aphek crushing the Aramean army). Ben-Hadad sues for peace as the now weaker party, and Ahab makes a covenant with him and spares him. He is then condemned by a prophet of YHWH: 'because you have released the man of my herem, your life will be in place of his life and your people in place of his people' (v. 42). The phrase 'man of my herem' is unusual, and this is the first mention that Ben-Hadad was under herem sentence. ${ }^{45}$ Nevertheless, Ahab is sentenced to death for breaching herem.

43 Moreover, there is far more divine involvement in chs. 6 and 10 than in ch. 8 (when the herem breach has been resolved).

44 More strikingly 6:25 (Rahab's survival) and 7:1 (condemnation of Achan's herem breach) are only separated by two verses outlining the curse on rebuilding Jericho. There are a number of other points of comparison between the stories of Rahab and Achan: both involve hiding something and spies sent by Joshua; the actions of the main protagonist affects their whole family; and both involve burning and conclude with 'to this day'. This suggests that they are meant to be read as a contrast or mirror to each other. More widely one can see the stories of Rahab, Achan, and the Gibeonites as a carefully crafted composition with the destruction of the Israelite Achan as a contrast to the surrounding preservation of the Canaanites.

45 It is possible that the herem flows from the nature of this conflict as YHWH war. However Stern, Herem, 178-83, argues against this association. 
The cases of Achan, Saul, and Ahab show how serious a herem breach can be. In each case there is explicit divine condemnation, and significant punishment. In contrast in the cases of Rahab and the Gibeonites there is no divine condemnation, and subsequent divine military support, which is arguably the opposite of punishment. Therefore, although Deuteronomy 7 and 20 do not explicitly give any exceptions, it does not seem that sparing the Gibeonites is a breach of herem. We will examine two possible reasons for this, the Israelite oath and the Gibeonite response.

\section{Possible Reasons for Non-breach of herem}

\subsection{The Importance of the Israelite Oath}

Israel has sworn some form of vassal treaty with the Gibeonites. Although we do not know the exact terms, such treaties often included the promise of protection for the vassal. ${ }^{46}$ Thus Gibeon call upon Israel and Israel responds. Importantly, the oath has been sworn in YHWH's name, thus making him the guarantor of the covenant. Therefore this could explain his surprising defence of the Gibeonites in chapter 10.47

This explanation does make sense of a number of points in the text. However it raises a theological question with regard to the portrayal of YHWH. The oath has been gained under deception, and Israel feels that they have no choice but to hold to it. Does this also apply to YHWH, so that in effect he is obliged to act to defend the Gibeonites?

It is certainly true that the Old Testament constantly portrays YHWH as one who keeps his promises. ${ }^{48}$ However this would not require YHWH to act here for three reasons. First, this is not an oath that YHWH has sworn, but one that was sworn by his people. Moreover it is an oath that goes against his own herem command, and therefore one that he would be expected to disapprove of. Numbers 30, while upholding the importance of an oath to YHWH (v. 2), nevertheless allows an oath by a woman to be nullified by a higher authority figure in the family (father or husband) if he disapproves or deems it to be

\footnotetext{
46 Fensham, 'Treaty', 99.

47 Fensham, 'Treaty', 99, cf. Polzin, Joshua, 122; Blenkinsopp, Gibeon, 36. An oath of protection is also sworn to Rahab, and Joshua upholds this, although there is no explicit divine action to protect Rahab in this case.

48 Exod. 34:6-7; Deut. 7:9; Ps. 136 etc.
} 
thoughtless. By analogy YHWH, as the ultimate authority figure, arguably should be able to overrule an oath by his people if he disapproves. The alternative would be that Israel can, by the swearing of an oath, manipulate YHWH into acting against his will.

Secondly, far from being manipulated by an oath sworn by another, YHWH is portrayed as one who feels free to release himself from oaths that even he has sworn. In 1 Samuel 2 YHWH negates the oath of perpetual priesthood that he swore to Eli's family because of the actions of Eli's sons. ${ }^{49}$ Two chapters later the Israelites attempt to gain YHWH's support in battle by bringing the ark of the covenant, the visible symbol of the covenant between YHWH and Israel. While both the Israelites and the Philistines believe that this will be effective, it leads to a greater failure and the capture of the ark, because of the underlying problems in the priesthood (1 Sam. 4:1-11). ${ }^{50}$

Thirdly, even if YHWH had been required to keep the oath, this would not necessarily stop him from demonstrating his displeasure upon Israel. However no such displeasure is evident. Contrast Exodus 32 and Numbers 14 where, even though YHWH'S own promises are mentioned and YHWH relents, he still shows displeasure by sending a plague upon the Israelites and causing them to wander for forty years respectively.

Therefore we cannot assume that the Israelite oath is enough to require YHWH to defend the Gibeonites if he disapproves of it. Returning to the idea of different perspectives, this explanation seems to be merging the perspectives of Israel and YHWH. The text portrays Israel as feeling constrained by the solemn oath that they have sworn. However there is no suggestion that YHWH is similarly constrained. We know from elsewhere in the Old Testament that Israel's perspective is not always the same as YHWH's. Therefore while the oath is probably part of the explanation, it does not seem to be a sufficient explanation by itself.

49 Jer. 18 sets this principle out in more detail. See ch. 4 of R. W. L. Moberly, Old Testament Theology: Reading the Hebrew Bible as Christian Scripture (Grand Rapids, MI: Baker, 2013).

50 This fits with the more general point in several prophets that religious observance will be rejected if accompanied by actions that break YHWH's covenant or commands (Isa. 1:11-17; Jer. 7:1-15; Amos 5:21-24). 


\subsection{The Importance of the Canaanite Response}

The other factor that marks out the Gibeonites and Rahab from others under herem is their confession or acknowledgement of YHWH. To consider why this is important, we need to consider the reasons for the herem command.

While Joshua shows Israel carrying out herem, it does not give the herem command or reasons for it. ${ }^{51}$ For this we need to look back to the Pentateuch. In the two most detailed passages, Deuteronomy 7 and 20 (and elsewhere), the same reason is given: Israel must herem the inhabitants because of the danger that they pose to Israel's relationship with YHWH $(7: 4,16,25-26 ; 20: 18)$. Israel is a holy people to YHWH, but living among the inhabitants and associating with them, will lead to following after their gods, and sinning against YHWH. ${ }^{52}$

If the danger posed by the Canaanites is the main reason for the herem, then the portrayal of the Gibeonites and Rahab becomes even more surprising. The Canaanites en masse are depicted as religiously dangerous. However the individuals that the Israelites actually encounter both give positive confessions of YHWH and positive responses to his people. ${ }^{53}$ They seem to be the opposite of a danger to Israel.

Moreover there is no suggestion in the wider Old Testament that the Gibeonites became a religious danger to Israel. ${ }^{54}$ On the contrary, in 2 Samuel 21 we hear of an attempt by Saul to annihilate the Gibeonites which results in a three year famine, showing YHWH's displeasure. If the Gibeonites had become a snare for Israel it seems inconceivable that YHWH would act in such a way. ${ }^{55}$ However, if their response was

51 Josh. 23:6-16 repeats the warnings in Deut. 7 about the dangers of intermarriage and serving their gods, but herem is not mentioned.

52 This warning is present in a number of passages, not all of which include herem: Exod. 23:23-33; 34:11-16; Lev. 18:24-29 (cf. vv. 3-5); Num. 33:50-56; Deut. 6:14-15; 7:1-6, 25-26; 18:9-14; 20:16-18.

53 Mitchell, Together, 169.

54 There is no further mention of Rahab in the Old Testament. In the New Testament the three references to her are overwhelmingly positive (Matt. 1:5; Heb. 11:31; Jas 2:25).

55 Even if there was any idea of oath constraint upon YHwH in Josh. 10, this would not be the case if Gibeon had drawn Israel into apostasy, as 1 Sam. 2 demonstrates. More widely, Gibeon is portrayed as an important shrine (1 Kgs 3:4), but it is not specifically associated with idolatry. It is notable that the preceding vv. 1-3 relativise the general condemnation of high places in Kings. Like the Gibeonites, Gibeon is ambiguous but not condemned. 
genuine, and they have not been a danger to Israel, it is understandable that YHWH would respond to uphold the oath sworn, as he did in Joshua 10.

This suggests that by responding positively to $\mathrm{YHWH}$, the Gibeonites and Rahab become exempted in some way from the herem that is due to the Canaanites. ${ }^{56}$ Ironically the Gibeonites tried to exempt themselves from herem by pretending that they came from outside the land, in a sense disassociating themselves from the other Canaanites. They achieved this disassociation in Israel's (mistaken) perspective, and in a different way in the perspective of the Canaanite kings (as 10:1-5 shows). However by siding with Israel and YHWH it could be said that they have been exempted in a fuller way in YHWH's (unmistaken) perspective. Thus the perspective of all of the groups within the story (kings, Gibeonites, Israel, YHWH) is that the Gibeonites are associated with Israel rather than the Canaanites. ${ }^{57}$ Therefore once again the narrator's perspective agrees with YHWH that the Gibeonites, associated with Israel, are exempted from herem.

This line of thinking has a startling implication for understanding the conquest. In Joshua we have two prominent examples of Canaanites coming to Israel and seeking to side with them and their God. Both are accepted. As these are the only such examples, we can go further and say that in the book of Joshua, any Canaanite under the sentence of herem who comes to Israel and YHWH is accepted, no matter how they come (including deception). No Canaanite is rejected by YHWH, and Israel is not punished for swearing an oath with any Canaanite.

It could be argued that two examples are a rather small sample on which to base such a claim. However against this is the point that these two examples (with Achan in the middle as a contrast) are so prominent in the story. Eslinger notes that, of all the conquest

56 In 1 Sam. 15:6 the Kenites are also exempted from divinely commanded herem because of their positive response to Israel, and this exemption is not condemned (in contrast to that of Agag and the best livestock). However the Kenites are different from the Gibeonites in that they are not subject to herem as a people.

57 Once again we need to be aware of what the text does and does not say. The Gibeonites are not explicitly described as coming into the covenant relationship with Yнwh, (although if the link with Deut. 29:10 is granted this may be implied). Neither, however, are they explicitly described as worshipping other Canaanite gods. See Dora Mbuwayesango, 'Joshua', in Global Bible Commentary, ed. Daniel Patte (Nashville, TN: Abingdon, 2004), 67; Blenkinsopp, Gibeon, 36. Moreover their association with YHWH's altar further distances them from the worship of other gods. What is clear is that they have chosen to side with Israel and YHWH against the other Canaanites. 
campaign descriptions in Joshua $1-12,47 \%$ is given over to describing Rahab, the Gibeonites, and Achan. ${ }^{58}$ In contrast the descriptions of the actual instances of herem are individually quite brief. This indicates that the main focus of the conquest narrative is not the execution of herem upon the Canaanites, but the salvation of Rahab and the Gibeonites in contrast to the destruction of Jericho and Achan, providing an interpretation of the meaning of herem.

\section{Theological Implications}

We will finish by considering the theological implications of the above points for the four groups in the narrative, starting with the Gibeonites. Although they are inhabitants within the land, they are not 'doomed to destruction' as we might expect. Thus, arguably, the kings and the rest of the Canaanites are not doomed either. Their response makes a difference.

One argument against this would be to point to 11:20 which explains the Canaanite kings' opposition to Israel as due to YHWH having hardened their hearts. However once again the Gibeonites appear as an exception to this. In the previous verse it is stated that no kings made peace with Israel, except the Hivites who lived in Gibeon. Once again if we ask 'What about the Canaanites?' (Why did God harden them?), we also have to ask 'What about the Gibeonites?' (Why were they, as Canaanites, still able to respond positively to YHWH? $)^{59}$ As this is an isolated hardening reference it should be read in light of the more detailed use of the hardening theme in Exodus 7-11, where the issues of perspective and response are also important. ${ }^{60}$

58 Eslinger, Hands, 52.

59 Eslinger answers this by suggesting that YHwH had mistakenly overlooked Rahab and the Gibeonites when hardening the other Canaanites (Eslinger, Hands, 45). Thus, as YHWH was partly to blame for their response and survival, this explains why he does not blame Israel for their failure to keep herem. However, as with the idea of oath constraint, this would contrast with the portrayal of YHWH elsewhere in the Old Testament. Moreover we would expect a more explicit mention of this exemption from the hardening.

60 William A. Ford, God, Pharaoh and Moses: Explaining the Lord's Actions in the Exodus Plagues Narrative, Paternoster Biblical Monographs (Milton Keynes: Paternoster, 2006), in particular 71-82 (on response), 113-24 (on perspective). Earl helpfully suggests that my approach to the hardening in Exodus can be applied to this verse as well and that in both cases the primary purpose of the hardening statements is 
This is not to say that the point of Joshua and the conquest was for all the Canaanites to side with Israel and YHWH. That would make a mockery of the herem commands. To return to the question of perspective we can note that the herem command is given to the Israelites because of the danger to them, rather than to the Canaanites ('you must die because you are a danger'). There is no message for the Canaanites at all. However those who proactively respond positively to what they have heard are accepted. This removes any image of Canaanites who desperately wanted to side with Israel and cried to out YHWH but were brutally ignored. ${ }^{61}$

This is also not to say that the Gibeonites (or Rahab) somehow deserve to be exempted from the herem because of their acts. However, as Polzin points out, Israel similarly does not deserve to be given the land. ${ }^{62}$ In both cases it is due to YHWH's mercy.

Moving on to Israel, these stories question any rigid understanding of Israel's identity as Hawk and Earl have argued in detail. Outsiders can become insiders and vice versa, depending upon what they do. ${ }^{63}$ This raises the wider question of what it means to be part of Israel, and how this is connected to one's response to Israel's God.

Finally, we come to YHWH. These stories show that YHWH is not implacably committed to the destruction of the Canaanites, come what may. Even the seemingly absolute herem commands are not without exception. This resonates with wider Old Testament prophetic

rhetorical (providing a different perspective that reassures Israel of God's sovereignty), rather than ontological (commenting on the inability of the Canaanites [or Pharaoh] to respond). Earl, Reading, 166-68.

61 To paraphrase a later Joshua (or Yeshua) in Matt. 7:8, these accounts seem to say that everyone who asks, receives (even Canaanites...). Furthermore, these reflections may aid our understanding of the encounter of Jesus and the Canaanite woman in Matt. $15: 21-28$. It is often seen as a difficult passage because of Jesus' initial words that seem to reject her (v. 24) and insult her (v. 26). Arguably, however, the surprising thing for the original reader would not be Jesus's initial words, but his subsequent, almost unparalleled commendation of her faith. A Canaanite comes to the representative of the God of Israel, is commended, and (like the Gibeonites and Rahab) receives what she asks for, even though she seems (initially) to be excluded.

The point is not as strong in Mark 7:24-30 where the woman is described as Greek/Syro-Phoenician. It could be argued that Matthew's description of this Gentile as Canaanite makes the situation worse. However the commendation argues against this, making it even more radical. It is possible that Matthew's telling of the story is based on an early reading of the conquest narrative in a similar vein to the one set out here.

62 Polzin, Moses, 120.

63 For summaries of their positions see Hawk, Joshua, 19-33; Earl, Reading, 197-203. 
messages that seem to have no hope and yet allow for response, even from Israel's enemies such as the Ninevites (Jon. 3:4, 10). This questions the image of YHWH that many readers find in the conquest narratives; a brutal, genocidal God who seeks and demands the destruction of an entire people regardless of their response. Instead the image of YHWH is much closer to that found elsewhere in the wider Old Testament. He can and will respond with destruction, whether it is to humanity as a whole (the flood), to Israel (the golden calf, albeit averted), or the Canaanites (the conquest). However it is not his preferred modus operandi in dealing with his creation. ${ }^{64} \mathrm{He}$ can and will respond with acceptance and mercy when people respond appropriately to him, even in the conquest.

Therefore, in the modern discussion about the ethical and theological problems raised by the conquest, one partial response to the question 'What about the Canaanites?' is the counter question 'What about the Gibeonites?'

64 This may provide some support for Williams' argument that YHWH commanded the destruction of the Canaanites with a heavy heart. (Williams, 'Could', 175.) 